\title{
Birth and evolution of systematic criminologies specific in Mexico origin, evolution and sistematización of the specific criminologies in Mexico
}

\begin{abstract}
This paper it's Focuses on highlighting the Importance of the criminology in Mexico specializing. It is taken as a reference to the specifics criminologies that have been developed in USA, Europe and other regions, Compared to those developed in the Mexican and Latinamerican bibliography. The objective is to highlight the need to create Importance and terms and conceptualize areas of specialized studies in criminology. So that, Have the professionals better tools of knowledge and make progress in the intervention With the phenomena of the criminality. Given the great contrast exists in Mexico that on the theoretical evolution of criminology With Other Countries of North America, Europe and Asia.
\end{abstract}

Keywords: areas, branches of the criminology, development, specialization
Volume 6 Issue 3 - 2018

\author{
Wael Hikal,' Roberto Alonso Ramos Erosa, ${ }^{2}$ \\ and Jorge Alberto Pérez Tolentino ${ }^{3}$ \\ 'Mexican Society of Criminology Chapter Nuevo Leon, Mexico \\ ${ }^{2}$ Criminological Brotherhood, Mexico \\ ${ }_{3}$ Mexico Gulf University, Mexico
}

Correspondence: Wael Hikal, Mexican Society of Criminology Chapter Nuevo Leon, Eduardo Livas 210, Nuevo periférico, San Nicolás, 66423, Nuevo León, México, Tel 5283524959, Email wshc1983.2013@gmail.com

Received: June 20, 2018 | Published: June 26, 2018

\section{Introduction}

Criminology in Mexico (and parts of Latin America) has been stuck in a generalizaste aspect of their field of scientific and professional development. The phenomena of contemporary crime surpass this theoretical and technical and professional skills. Criminology needs to be redefined in its theoretical platform to redesign practice this scientific achievements, academic, and industrial applications. ${ }^{1,2}$ This is a theoretical review and proposal on the areas of expertise that could be of criminology, and on which we could develop occupationally criminologists, as scientific creation and implementation of techniques and approaches to the criminal phenomenon. We believe that knowledge is a source to analyze, understand and interpret the events surrounding the life of human beings, and within this, and their own creations. With such knowledge, and with the arrival of phenomena that become social and individual problems can be addressed with knowledge describing such. Being crime, a present situation in almost every country in the world of constant and impactful way, to the extent that knowledge plays this problem, this has been drawn in the last 100 years in criminology, and other branches of sciences, such as sociology, psychology, among others.

Crime suffered in Mexico and Latin America has been increasing in very short periods of mankind; ie in the last 15 years, an explosion of criminal phenomena, impunity, corruption, abuse of power, authority, diversion of resources, organized crime, violence in various contexts, murder, criminal operations has occurred from inside prisons, public officials detected as criminals, but acquitted. Also, an increase in inequality, poverty, unemployment, low wages, poor education, slum development opportunities, among other conflicts that are destroying humanity in Mexican and Latin regions. This paper exposes various terms and concepts, based on psychology, law and specialized
Sociologies as well as the specific criminologies developed in other regions such as USA, Europe and Asia, offering its adaptation to the Mexican Criminology, besides conceptualising, possible areas of application of such a specialized area, and the progress that has been made in several areas, work, literary and progress on the beginnings of the specific criminologies level education are proposed. On the other hand, the diagnosis made for the detection of the literature on the subject, which has been published in the above mentioned regions is presented, another topic considered was the number of schools offering degrees in criminal matters, limited only to Mexico,

\section{Methodology}

For the realization of this work were relied on the following sources of information:

i. Consultation classic books -at scope of acquisition- of Criminology in Mexico and Latin America on specialization.

ii. Web search for schools offering all levels of education undergraduate and graduate, as well as visiting some of these to survey and observe the curriculum.

iii. Search and compare consultation with the catalog of books and magazines Criminology Routledge. Taylor \& Francis Group (USA and England), publisher and distributor Flores (Mexico) and Editorial Porrúa (Mexico), among others, and American Society of Criminology, to detect specialized books.

\section{What is the importance of specialization?}

A basic premise, which should always be assumed to produce knowledge, it is consistent that science is at the service of society and this is so for the reason that those responsible for producing scientific 
knowledge are precisely members of the community and further, it can be said with certainty that it is privileged members in the sense that they have the necessary tools to assist in driving the drive wires of the collective good. Unfortunately, in various areas of knowledge, and that corresponds to us in criminology, it has been plagued with characters who take advantage of different situations for individualists purposes, curricular, economic and prestige growth, distancing themselves from the collective benefit or social work. Namely, among others:

i. Morbid by newly admitted to the professions of criminologyForensic;

ii. Fanaticism that has been generated by classical figures;

iii. The desire for fame, and

iv. Harnessing the lack of involvement of criminologistscriminalists in academic subjects.

In Mexico, as in the whole planet, scientific knowledge has a fundamental role in the transformation of everyday life, the difference with other countries, relative to the amount of science that leads to effect its contribution to the social system, and the quality of scientific papers presented; in our sphere of validity, unfortunately, not all science specialists make contributions that benefit the country.

If the main purpose of science is to benefit the community, they can clearly noted two situations:

i. The secondary purposes, and

ii. Means to carry it out.

Science, to meet its pristine target, aim to produce, develop, disseminate and apply knowledge; These purposes are intrinsically intertwined, so that cannot be isolated without the harmful consequences that implies, in other words, without the severe fracture that involves the indiscriminate removal of the purposes indicated. In Mexico, secondary aims of science have not been fulfilled, in recent decades has only been spread profusely, the criminological area, however, quite regret, only general comments are reproduced, being detached from the tree of Scientific Criminology: production, development and application of knowledge obtained simply does not exist and has never existed. As for the stages for the development of scientific knowledge, one of the basic issues in the generation of knowledge is the analytical division of the various parts that make up a particular scientific area, in order to look closely at the problems there are presented to, subsequently to systematize properly; Consequently, by using scientific logic it is needed:

a. Look closely at the problems together;

b. Separate scientifically the problem into as many parts as deemed necessary;

c. Develop knowledge in each of the plots thereof;

d. Disseminate the results of scientific studies, in order to show results;

e. Concatenating specific studies to properly systematize the whole of the science in question, and

f. Lead, through the bridges are required, the application of knowledge.
In the field of Mexican Criminology, laboriously warns that the 70 of the past to the present, in general, has been made, moderately century, the first of the reported points, that is, concerning the observation of the problem, remaining as a liability, which daily increases, the remaining points. Says Peters, the creation of forums where you place the researchers give for the exchange of research and opinions, as well as promoting stimulus through awards for research "must be regarded as a major step toward defining the profile criminology as an academic discipline ". ${ }^{1}$ It is clear that in Mexico, criminology has been unable to achieve the primary objective of science, since you cannot expect an outcome if not carried to effect the necessary actions to achieve; concatenating concerning secondary purposes and stages to generate scientific knowledge, it is reiterated that in our country, the criminological area has been the gateway to the scientific field, complying with the spread of very general observations that in any way, contribute to the improvement of the country. It is understandable that in the genesis of criminology in Mexico have made efforts to publicize the generalities of this area of knowledge, however, many decades of existence, the idea remains the same: General comments that do not benefit the community, which hoped that the privileged members collaborate actively in reducing many problems that affect everyday life.

\section{Special features of the specific criminologies}

i. They represent the next and necessary step in the evolution of knowledge of the Mexican Criminology, since they are a very important advance in relation to anachronism in which In full second decade of the century! Mexico remains in this area;

ii. They are the starting point for scientific development in each of the various areas of knowledge that can sever the Mexican Criminology, serving clean and jerk to obtain, at the time, required systematization and

iii. Their mission is their studies can be applied, despite the difficulties involved in Mexican politics, and towards the community.

Then a comparative charts about science in general, the Mexican Criminology and specific criminologies shown:

But why the need to specialize in criminology? Indicates Peters, "to be a secondary discipline or assistant legal, social science and even medical, the last criminology to become an entity of academic and scientific activities, autonomous and often even independent". ${ }^{1}$

\section{The daily literature found in Mexico}

During consultations libraries and bookstores in search of material on criminology, the following results and reflections: books Criminology same name, strange situation is that professionals of criminology have failed to specialize the branched knowledge in various areas on par with other sciences, such as:

a. A library of Psychology What is? Educational books, Family Psychology, Military, Engineering, of accidents, Colors, Cognitive, Personality, behavioral, physiological, and many more in their specialization;

b. In a law library What is? Fiscal, Electoral, Commercial, Municipal, Criminal, Environmental, Marine, Aviation, Constitutional, Municipal, among many, and right 
c. A library of Criminology What is? The books have similar titles, without specifying their field of study beyond introductory notions. On the other hand, there are very few specialized degrees in excess of generality.

On the previous paragraph, it should be noted:

Theoretical such disparities are sometimes and sometimes are the result of poor information (...). However, the landscape of literature professorships has, for one reason or another, a mosaic whose negative is the lack of knowledge that causes when making policy decisions and allowing any criminal without criminological training (...) embark for reasons of vanity or power campaigns "law and order" or "mind distraction". ${ }^{3}$

Here they are placed in chronological order the most common (or unique) general and specific titles that can be found:4,5

i. Criminalistics and Criminology notions (Moreno Gonzalez and Rodriguez Manzanera, 2017)

ii. Criminological science in preventing and their uses (Hernández Monroy Castillo and Ojeda, 2016)

iii. Treaty of Criminology (Reyes Calderon, 2017)

iv. Current Essentials of Criminology (Cerezo Dominguez, Gimenez-Salinas Framis Court Ibáñez, and of Aebi, 2017)

v. Criminology. The crime victim (Marchiori, 2017)

vi. General rules of Criminology and Criminal Policy (Vidaurri Aréchiga, 2016)

vii. Introduction to the Study of criminology (Hikal, 2016)

viii. Manual Criminology (Orellana Wiarco, 2016)

ix. Criminology. Basic concepts (O’Brien and Yar, 2016)

x. Criminology (Rodriguez Manzanera, 2016)

xi. Criminology (González Vidaurri and Sanchez Sandoval, 2016)

xii. Introduction to Criminology and the criminal justice system (Larrauri, 2015)

xiii. Criminology. Theories and thoughts (Marchiori, 2014)

xiv. Manual Criminology (Perez KASPARIAN, 2014)

xv. Theories of criminality (Lamnek, 2013)

xvi. Principles criminology (Santiago Redondo, 2013)

xvii. Manual Criminology (Barrita López, 2013)

xviii. Criminology and antisocial behavior (Silva Rodriguez, 2013)

xix. Notions of Criminology (Reynoso Dávila, 2012)

xx. Criminology. Modern and contemporary (Wiarco Orellana, 2012)

xxi. Manual Criminology (Maguire, Morgan and Reiner, 2012)

xxii. Contemporary criminology. Introduction to its theoretical foundations(Pámanes Palacios, 2012) xxiii. Criminology (Marquez Piñero, 2010)

xxiv. Criminology (López Vergara, 2008)

xxv. antisocial behavior: A psychological approach (Silva Rodriguez, 2008)

xxvi. Criminology (Tamarit Sumalla, 2009)

xxvii. Criminology, Criminology and Victimology (Silver Moon, 2009)

xxviii. Critical Criminology heritage (Larrauri, 2009)

xxix. The reason absent. Essay on criminology and political criticism(Virgolini, 2005)

xxx. Criminology course (Pérez Pérez Pinzón and Castro, 2005)

xxxi. Treaty of Criminology (Tieghi, 2004)

xxxii. Criminology dynamics. Essays, reflections and proposals clinical criminological (Mariela Trujillo, 2004)

xxxiii. criminologyto (Echandía Reyes, 2004)

xxxiv. Criminality. Science, Philosophy and Prevention (Tieghi, 2004)

xxxv. Criminology. A humanistic approach(Fontalvo Restrepo, 2002)

xxxvi. The new Criminology (Taylor, Walton and Young, 2001)

xxxvii. Manual Criminology (Elbert, 2001)

xxxviii. Latin American criminology. part One (Elbert, 1996)

xxxix. Latin American criminology. part Two (Elbert, 1999)

xl. Criminology of the XXI century in Latin America (Elbert, 1999)

xli. Criminology and human dignity. dialogues (Beristain and Neuman, 1989)

xlii. Criminology. Approach from a margin(Zaffaroni, 1988)

xliii. Crime and Justice in Latin America (Rico, 1981)

Specialized books about:

a. Fundamentals of Endocrinology and Criminology (Even Weor, 2017)

b. Contemporary Clinical Criminology (Palacios Pámanes, 2017)

c. black book teaching criminology in Mexico (Hikal, Perez Tolentino and Erosa Ramos, 2016)

d. Guide for writing thesis and other research work for students of Criminology-Criminalistics (Hikal, 2016)

e. Classics of Criminology (Rodriguez Manzanera, 2016)

f. Psychological Criminology (Hikal, 2016)

g. Clinical Criminology (Rodriguez Manzanera, 2016)

h. Etiological criminology-multifactorial (Hikal, 2015)

i. Glossary of Criminology, Criminology and Victimology Criminal (Hikal, 2015) 
j. Specialized criminologies (Gomez Tagle Lopez, 2014)

k. White Paper teaching criminology in Mexico (Rodriguez Manzanera, 2014)

1. Criminology Human Rights (Hikal, 2013)

m. Glossary of Criminology, Criminology and Victimology Criminal (Hikal, 2015)

n. Chromatic criminology (Ferro Veiga, 2014)

o. Female criminality. Theory and social reaction (Lima Malvido, 2014)

p. Juvenile Delinquency (Rodriguez Manzanera, 2014)

q. Field criminology. victimales criminals and profiles(Echeverria Solano, 2012)

r. Environmental Criminology (Vozmediano Sanz and Guillen, 2011)

s. Reflexive criminology. Discussions about crime (Cunjama Ordaz Hernandez and Lopez, 2011)

t. Criminology in the works of William Shakespeare (Hill Rubio, 2005)

The above aspect leads to compare the production of books in other subjects such as Social Work, Sociology, Law, Psychology, Medicine, among others, which casts production in Criminology has been generalist and redundant, although the knowledge in criminal cases is not limited to books endogenous Criminology, this production is dispersed, or as noted Zaffaroni: “(...) and many of its publications are really ephemeral". ${ }^{3}$ That is, the social worker makes studies on violence and systematized such, but in order to pay for your area, for example Freud, this did Criminology, but Psicoanálisis, giving contributions to the criminal, but not essentially contribute to Criminology. On the above, over the years, it was creating knowledge in criminal matters derived from other areas, criminologists (graduate level) in training, briefly systematized this knowledge and embodied in books of Criminology, but it happened a static trend, there was something innovative, no specialized criminologies, and research conducted by trained undergraduate degrees criminologists (some have done postgraduate studies, but without scientific and participative involvement in events and outreach), they have not been most shocking. In fact, the previous list of books, less than five authors are criminologists basic degree; ie have conducted studies of Criminology in syllabi criminal law, criminal Psychology, Criminology graduate. It what is the importance of a criminologist degree specializes in scientific research?1,2 What if the medical books were written mostly or entirely by empirical or by biologists, veterinarians, nurses or medicine? What value would a math book written by a psychologist? Or what value would a law book, written by a teacher? Their contributions can not detract, but there can be a miscellany of research lines in an investigator, or make a contribution and then leave while in Mexico Why criminology does not progress? Note that this work is not limited to classical literature, conferences or similar, as participants of the above, are the same in a one to five decades between, Points Zaffaroni: "Obviously criminological research in Latin America does not meet the qualitative and quantitative levels of the central countries, due to the limited resources allocated to it and the limited official encouragement".

Note the following comparative table of specializations only four sciences: sociology, law, psychology and medicine, in contrast to the Mexican Criminology.

\begin{tabular}{|c|c|c|c|c|}
\hline Specialized sociology & Specialized law & Psychologies specialized in & Specialized medicine & Criminology in Mexico (types) \\
\hline Theater & Civil & Job & Aerospace & Review \\
\hline Zoosociología & Penal & Industrial & Job & Clinic \\
\hline Rural & Trade & Colors & Family & academics \\
\hline Radical & Environmental & Military & ER & applied \\
\hline Math & Electoral & Art & Sport & scientific \\
\hline Marxist & Sport & Humana & intensive & \\
\hline fenomenológica & Doctor & Animal & internal & \\
\hline Review & Space & Social & Legal & \\
\hline \multirow[t]{2}{*}{ comparative } & Aeronautical & Engineering & Forensic & \\
\hline & & & & Analytics \\
\hline applied & Constitutional & Health & preventive & \\
\hline Job & $\operatorname{Tax}$ & humanitarian & Public health & \\
\hline Professions & Diplomatic & War & Physical & \\
\hline Computing & International & Emergency & According: & \\
\hline
\end{tabular}


Table Continued...

\begin{tabular}{|c|c|c|c|c|}
\hline Specialized sociology & Specialized law & Psychologies specialized in & Specialized medicine & Criminology in Mexico (types) \\
\hline sociometry & Municipal & Forensic & Gender & \\
\hline Industry & Labor & Clinic & Body part & \\
\hline Economic development & Procedural & Abnormal & surgical process & \\
\hline Consumption & Roman & educational & & \\
\hline Revolution & Canonical & Children and Youth & & \\
\hline Politic party & Public & Fisológica & & \\
\hline Imperialism & Private & Adolescence & & \\
\hline Suicide & Economic & addictions & & \\
\hline Woman & Agrarian & Video game & & \\
\hline Religion & computer & Development & & \\
\hline Armed forces & Sanitary & Conductual & & \\
\hline Fascism & Town & applied & & \\
\hline Mental diseases & Banking & Emotions & & \\
\hline Music & Corporate & Sport & & \\
\hline Medicine & Protection & Sex & & \\
\hline fashion & Fiscal & Marketing & & \\
\hline Law & Commerce & Experimental & & \\
\hline Sport & Humans & Couple & & \\
\hline Culture & Social Security & Family & & \\
\hline Knowledge & Parliamentary & Environmental & & \\
\hline Science & Demographic & & & \\
\hline Art & bioethical & & & \\
\hline Aine & Compared & & & \\
\hline City & Maritime & & & \\
\hline Education & Indigenous & & & \\
\hline Criminal & Social & & & \\
\hline \multicolumn{5}{|l|}{ Sex } \\
\hline \multicolumn{5}{|l|}{ Labor union } \\
\hline \multicolumn{5}{|l|}{ Language } \\
\hline \multicolumn{5}{|l|}{ Family } \\
\hline Company & & & & \\
\hline
\end{tabular}


In contrast, through the catalog of books of Criminology, only Routledge. Taylor \& Francis Group (2017), there are the following books, among many others:
a. Criminology homosexuality
b. Criminological research for beginners
c. Manual International Criminology
d. Alternative criminologies
e. Cultural Criminology

f. Cyber Criminology

g. Rural criminology

h. Positive criminology

i. The new European Criminology

j. Liquid criminology

k. Psychiatric criminology

1. Biosocial criminology

m. Chinese manual Criminology

n. Criminology and war

o. Environmental criminology

p. Criminology, race, gender

q. Criminology, theory and terrorism

r. Visual criminology

s. Green criminology

t. Criminology war

u. Women, Crime and Criminology

v. Existential criminology

w. Public Criminology

x. Psychological Criminology

y. Feminist Criminology

z. Transnational and Comparative Criminology

aa. Forensic Criminology

ab. Epidemiological Criminology

\section{The arrival of a general criminology in Mexico}

Undoubtedly the most commercial research in criminology (following Quiroz Cuarón) of the 70's, 80's, 90's and first two decades of the 2000 ( 50 years ...), has been: Rodríguez Manzanera, he being, forming many now criminologists and criminalists bachelor's, master's and Ph.D., in his book Criminology ${ }^{6}$ is criminological synthesis, referring to Criminology Anthropology, Criminology Psychology, Criminology Sociological, among others, and highlights that in some countries the trend is varied, in some biological and Italy and other sociological and USA.

From the above, it is noted that in Mexico, and several countries in
Latin America the trend is synthetic-static (there has been publishing novelty or specialization). In the books listed above, most (Mexican), emphasize the areas of criminology only four, following López Rey Y Arrojo:

i. Scientific criminology;

ii. Applied Criminology;

iii. Academic criminology, and

iv. Analytical criminology.

Where in these, they rest all areas of criminological exercise, but strangely, there is no book that bears the title of any of these above, except some approximations of Criminology Academic, ${ }^{7}$ Analytical and Criminology (Hikal ${ }^{8-10}$ and Cunjama Ordaz Hernandez and Lopez, 2011) found in the above list of specialized books. That is, only limited to short chapters in books.

In addition, it has proliferated and again stalled the trend of seemingly two types of criminologies in Mexico and Latin America:

i. Critical criminology, and

ii. Clinical Criminology

And even stranger, there are self-appointed critics and clinical criminologists criminologists where in Critical Criminology, grouped branches: Sociological, political, women's, marginal, child and adolescent, human rights, among others, but not exactly as specialized criminologies. And in the second, biological, psychological, and those with proximity to the internal human currents. The alarming thing to be noted is that the curricula of Criminology in Mexico, correspond to the etiology of criminality, but these critical criminologists, point to the etiology as merely biological causes, on the other hand, has not been detected until today, any public or private institution granting the degree of critical or clinical criminologist. We are not referring in this study to a mere terminological gap; ie not only we propose new terms arising from the General Criminology, specialized in some area where there is crime, but thick and specific studies on the subject, but by operators of criminology; i.e., criminologists, because in Mexico, static tendency is to criminology General, although the developed psychologists, lawyers, lawyers, social workers, doctors, and others have not focused the specialized areas of study Criminology. What will the current context hundreds of books of introduction to any of the above areas? Mexico deserves and situation of violence, the generation of specific knowledge.

\section{Alarming figures}

particular case in Mexico is that the only census ${ }^{11}$ unofficially made (not by the US Department of Education or states in Mexico), has thrown 445 schools offering teaching at three levels: bachelor's, master's and doctoral degrees, this, with curricula of Criminology and / or Criminology, criminal Psychology, Public Safety, Private Security, criminal science, criminal, victimales, forensic, and similar terminologies, the which for the first, more than 350, the second, about 50, and the third, less than 10 institutions. So if there are so many schools and there are so many graduates criminology Why does not evolve? "In many of these centers postgraduate courses sometimes have a limited life a few years (...)". ${ }^{3}$ The previous census does not include optional subjects ranging in courses of law, psychology, medicine, sociology, social work or other, which is 
given option or part of terminal studies the criminal area, does not consider postgraduate studies in Criminal Law, but strictly limited to graduates as mentioned at the beginning of these figures. Graduates of bachelor's degrees in criminology-Criminalistics have placed all the work of scientific research in the now classic respectively in your area: Rodríguez Manzanera, Lima Malvido, Villanueva Castilleja, Montiel Sosa Garcia Ramirez, Moreno González, Sánchez Galindo and some already deceased as Tocaven García Solis Quiroga, Carrancá and Trujillo, Quiroz Cuarón, among others. Thus the passage of the years there have been great developments in science, whether the proliferation of schools ${ }^{11}$ but with no academic researchers, just being on the lookout for what others foreign or classic books provide with refried each other.

Crime that currently has the world requires new knowledge to shape laws and public policies to address and prevent crime, as well as reforming the academic systems in schools. ${ }^{2}$ From the above, it is the need for analysis and development of this and criminologies proposals, to be deployed, modify and improve through the philosophical, academic and scientific exercise. "There is a growing need for this type of specialized professionals, as local, national and international organizations have a duty to inform the public about its activities and policies regarding crime and criminal justice". ${ }^{1}$ Another fact that alarm, is the number of national scientists, and recognized by Mexico, in there is the National Council for Science and Technology (CONACYT), created as a decentralized institution of the federal government, also responsible for creating policies for science and technology country, whose task is to promote national scientific and technological development, linking academia with business, human resources and training high level. ${ }^{12,13}$ On the other hand, the National Research System (SNI) was created in 1984 as a means of recognition of researchers dedicated to producing scientific and technological knowledge, through an appointment as national researcher at various levels and financial stimulus. ${ }^{14}$

In Mexico, by 2017, there are 27.186 national researchers, of which the last published annual list were identified only 25 in the areas of criminal knowledge (Criminal Psychology, sociopathy, Criminology, Criminal Policy Victimology, none for Criminalistics), ${ }^{15-17}$ his bachelor of origin of those points are known:

1. Dr. Luis Alejandro Astorga Almanza

2. Dr. Pablo Jesus Gonzalez Reyes (sociologist)

3. Dr. Victor Alejandro Paya Porres (sociologist)

4. Dra. Rebeca Elizabeth Lopez Contreras (lawyer)

5. Dr. Rogelio Alvarez Barba (lawyer)

6. Dr. Juan Federico Arriola Cantero (lawyer)

7. Dr. Gustavo Javier Fondevila (philosopher)

8. Dra. Guadalupe García García

9. Dr. Jose Angel Mendez Rivera (lawyer)

10. Dr. Jacobo Herrera Rodríguez (psychologist)

11. Dra. Lizbeth Garcia Montoya (lawyer)

12. Dra. Martha Fabiola García Álvarez (lawyer)

13. Dra. María Teresa Ambrosio Morales (lawyer)

\section{Dr. Erick Gomez Tagle-López (sociologist)}

15. Dr. Gerardo González Ascensio (lawyer)

16. Mtro. Martin Gabriel Barrón Cruz (historian)

17. Dr. Julio César Kala (pedagogue)

18. Dra. Maria De La Luz Lima Malvido (lawyer)

19. Dr. Luis Rodríguez Manzanera (lawyer and psychologist)

20. Mtra. Sierra María Pacheco (lawyer)

21. Dr. Eduardo Lozano Tovar (lawyer)

22. Dr. José Zamora Grant (lawyer)

23. Dra. Karla Villarreal Sotelo (only criminologist degree)

24. Dra. Cynthia Marisol Vargas Orozco (only criminologist degree)

25. Dr. Gil David Hernandez Castillo (only criminologist degree)

Of the above, only three are criminologists basic degree, postgraduate degree in other areas of knowledge, the rest, lawyers, teachers, a historian, psychologists, sociologists, among others. The result is striking is that although science is interdisciplinary, the trend is generating its own researchers, knowledge; ie not all knowledge in circumference, but from within. Two other data alarming are, there is only one institution recognized by CONACYT as public center of knowledge generation in criminal matters: National Institute of Penal Sciences ${ }^{13}$ and in the area of graduate programs: Single $\mathrm{PhD}$ doctorate in Criminology (University of Nuevo León, 2014), is supported by the same, while only two master's degrees: Master of Criminology and Forensic Sciences at the Autonomous University of Tamaulipas, and Master of Forensic Medicine at the Universidad Veracruzana they are in the same situation (National Council of Science and Technology, 2017), through the National Quality Graduate Studies Program (PNPC). This recognition implies quality standards by institutions that posit, as full-time faculty dedicated to teaching and research, with profile continuous improvement in teaching methodology and knowledge generation, among other features. What might be normal for other countries. Compared to other areas of knowledge such as Physics, Engineering, Medicine, Law, Education, Psychology, and others, they are much more abundant. On the side of national researchers, it is the same situation, the remaining more than 20,000 are from other areas, and $1 \%$ to the criminal.

\section{Moving towards specialization in Criminology}

The General Criminology in Mexico, attributed the objectssubjects: antisocial personality victim, social control, scientific development, Pedagogy, criminogenesis, criminodinámica, biopsychosocial etiology of criminal and victim, crime prevention and the treatment of offenders and victim. And yes, most of the concepts (however synthetic whatever) usually farsighted, it is unknown at what point was introduced as part of the subject of study of criminology, the Victimology "General" and victims "General "which, if specified at a time when victims of crime, but it leaves ample to victims of natural disasters, diseases, and other types. Criminologist can no longer be the "todólogo" as far occurs (at any level: Undergraduate or graduate), no matter how skilled you are or good grades to load in their curriculum materials, cannot exist criminologist who play as Preventólogo, clinical, diagnostician, rehabilitator, political scientist, juvenile, organized crime, public safety, intelligence, polygraph, 
of, environmentalist, school, academic human rights. Whereas itself already is unfortunate the low professional level exhibited by some criminologists, unable to support theories against other professionals. See other professions such as law, no criminal lawyers, environmentalists, tax specialists, mercantilist, labor, military, customs, electoral, constitutional, family, among others, but everyone is going specializing in the area of interest. Medicine, no doctors, "todólogos" gynecologists, pediatricians, cardiologists, psychiatrists, urologists, anesthesiologists, emergency, internist, pathologist, and so on. And finally, there is no multiple action psychologists, social, labor, children, psychoanalytical, behavioral, among other educational area. If so there would be a "super professional" (commonly those who have been long years in the study and elderly, for example: Ministers of the Supreme Court of Justice of the Nation).

\section{Is it required to start with a criminol philosophyorlogic and epistemology criminolorlogic?}

Philosophy provides the logical foundation of science, or ideas concerning ways we can acquire knowledge, all progress requires a philosophical process. Philosophy of science refers to the philosophical examination of science; ie its problems, methods, techniques, logical structure, overall results, etc. and if science is able to reveal the truth, this will also can be called as an epistemological examination; ie question to its logical conclusion knowledge to find its origin and reality (Gutiérrez Sáenz, 2002). Criminological Philosophy (term coined in Mexico, first by Agustín Salgado García) is part of the general philosophy that refers to the process of thinking about everything related to criminology, it collects all the useful knowledge for understanding antisocial phenomenon, methodology, body of knowledge, theories, thoughts, is a buildup that never ends. This (ideal conceptualization) Philosophy has been done for centuries, it is linked with ideas for understanding antisocial behavior. Today it is done with the intention of finding new forms of treatment for antisocial phenomena and applying the knowledge of other sciences criminology; and of course, the analysis of criminology itself to improve it and understand it more. A philosophy of criminology not only give us the logical foundation that requires science to be called so; or concepts that they must be analyzed der. A Criminological Philosophy, will mainly basis for the existence of criminology, ie grant us why criminology. To do so, within philosophy there are three main branches should be a priority for Criminology: Ontology, Epistemology and Ethics.

The first is the study der being, there is, of what exists, of the material and the immaterial. Within immaterial, we can bracket the "ideas", the world gnoseológico. Ontology of criminology, you can provide us why criminology as a science. The first existential track, we can find in the theory of Ideas of Plato, the idea of "evil". Although a deeper and abundant study would be needed, we can say that criminology exists, because "evil" exists, whatever the culture, country or religion, there is always a sense of "evil", which seeks to be prevented and punished. And "evil" gives us an object of study and in turn gives existential foundation to Criminology. Epistemology meanwhile, is the way how we know what exists. Ontology exists in the world of the senses and the world of the intelligible, and Epistemology is what gives us the tools to meet these two worlds; in the sensible world are the shadows, they are things that do not directly see (as well explained by Plato in the famous "Myth of the Cave") the way in which we know or represent these shadows is through the imagination, in the same world are sensible objects, what we see, how we know how sensitive these objects is through belief. In the world of the intelligible are the numbers, which we know through discursive reason, they are superior to sensory knowledge. But they are not completely independent object world of the senses. And finally we find the ideas and we access them through the intelligence. With the foregoing realize that the idea of "evil" we got through intelligence, but even more important is access to the idea of "good", "justice", among others: For they are ideas as necessary as fundamental for the existence of criminology and later studied.

The ideas of "good" and "evil" not only give purpose and object of study criminology, but also establish normative-ethical guidelines to criminologist. The Ethics is the branch of philosophy that deals with the duty-being. Ethical standards should be created from the ideas that we saw before and for this reason is necessary, for this reason, the Ethics is presented as a conjunction between Ontology and Ethics. The criminologist should be aware that ethical conduct is required (as in all other sciences, do not start with the game of omnipotence) in their profession. But establishing such conduct involves know as professionals and know our profession. Still common that you ask a student what it is criminology and one answer a string of inconsistencies only lead to the issuer of the question to more confusion. Deontology is presented as a branch of the essential philosophy in criminology and criminologist should develop in order to be properly implemented in the curriculum and not just go milling around who are criminologists, because for such a claim must be fully aware that criminology, besides all, is a science that leads down the path of ethics, after then, the criminologist is an ethical entity.

\section{Specialized criminologies}

Specific or specialized criminologies are composed of body grown in a "specific" area of criminality knowledge, it seeks to go beyond the generality and piling up of objects-subjects study one General Criminology (and operators) and seeks to create monographs on topics of interest, but also including what to do criminologist in this specialized area to grow academically and overcome criminological theory of chaos. It is not impulsive and without order, but under an analytical and progressive regime creations. To all this you will have to name as "NeoCriminología School" or "School of Contemporary Criminology". ${ }^{18,19}$ Achieved the above, it may be a Systematic Criminology and not the ordinary General Criminology, which actually is the product derived and synthesized from many other sciences. While it is clear that many professions and sciences or disciplines are born from the synthesis of other, there are some who have the ability to become independent and start creating own knowledge and foundations that give rise to something innovative, that has happened to others and such once this would be the triumph of Philosophy: Create more knowledge applicable and verifiable, as well as growing.

All this corresponds to a new series of neocriminólogos give birth to specialization and areas to implement the practice. Below are listed and defined some of the criminologies that could be developed in different regions of our continent. "An essential feature of criminology as an academic institution scientific activities, is the combination and integration of perspectives and policy approaches, socio-empirical and ethical". ${ }^{1}$ 


\section{Advances in the development of specific criminologies}

In this paper we will frame the advances in the art in the following aspects: terminologies and conceptualizations; book publishing and specific items, curricula that include specific criminologies, specialized magazines, and finally, the awards given to scientific research.

"Overall, we can say that despite all the difficulties, interest in criminological research is growing". ${ }^{3}$

\section{Terms and concepts}

Three authors are in Mexico, who have developed the most obvious specific criminologies so, in chronological order:
a. Reyes Calderon ${ }^{20}$;
b. Hikal, ${ }^{8}$ and
c. Gomez Tagle ${ }^{21}$

The revival of the specific criminologies in Mexico, emerged in 2004 with the writing of the text initially entitled "Criminology" of Hikal, registered with the National Institute of Copyright, in 2005 and first published in 2009 under the title of Introduction the study of criminology (Hikal, 2009) with stamp Editorial Porrua, taken from reference books classics like Zaffaroni ${ }^{22}$ "behavioral Criminology", "biological Criminology", "psychoanalytic criminology", including derivative terms socialism; Tieghi ${ }^{23}$ "Experimental criminology", "biological criminology", "criminal Reflexología", among others; Nicéforo, "biological Criminology", "Psychological Criminology" among others; Von Hentig; Drapkin ${ }^{24}$ with "Criminology of Violence" in Mexico, Tocaven Garcia. ${ }^{25}$ The following lists the most popularized terms of specific criminologies in the Mexican context and other regions (known in Mexico as well), organized and developed by the three authors mentioned above, in addition, will seek to mention other authors and years who have worked will be presented term in books, articles or other means of institutional disclosure.

Later, they were detected in the work Criminology Reyes Calderon ${ }^{20}$ various terms and concepts that were introduced in the Glossary of Criminology, Criminology and Criminal Victimology ${ }^{18}$ and black book teaching criminology in Mexico. ${ }^{11}$ These, systematized by Reyes Calderon ${ }^{20}$ were:
a. Criminology Peace
b. Criminology of social reaction ${ }^{26}$
c. Etiological criminology $8,18,27-30$
d. Ethnic Criminology $y^{30-33}$
e. radical criminology $3,34,35$
f. social criminology $y^{36-42}$
g. Socialist criminology $42-49$
h. Sociological Criminology
i. criminology unit.

From 2009 to 2017, Hikal, led some terminologies and concepts, namely:
1. Biological criminology $y^{38}$

2. Comparative Criminology

3. Behavioral Criminology (Criminal Reflexología $)^{41}$

4. Criminology social counseling

5. Criminology personality

6. Art criminology

7. Criminology health

8. Criminology addictive behaviors

9. Developmental criminology

10. Demographic criminology

11. Educational criminology

12. Etiological criminology-multifactorial

13. Space criminology

14. Space criminology (and Forensic Astronomy, coined by Julio Cesar Garcia Luna)

15. Women criminology

16. Infant-juvenile criminology

17. Computer criminology

18. Forensic Criminology

19. Criminal law Criminology

20. Labor criminology

21. Psychiatric criminology

22. Transcultural criminology

23. Victimhood criminology

24. Transcultural criminology

25. Criminology Sport

26. criminology prison

27. Criminology Human Rights ${ }^{26}$

28. Criminology vial (worked by Jose Maria Gonzalez Gonzalez and Juan Antonio racecar Espallardo)

In 2014, Gomez Tagle coordinates and publishes the book criminologies Specialized, with introduction on these areas of knowledge and various theoretical and field cases framed in various specializations, of which reviews the following terminologies without concept stand out.

1) Environmental criminology

2) Criminology Sport

3) Police criminology phenomenon

4) Family criminology

5) Police Criminology 

6) Corporate criminology
7) Criminology gender
8) Criminology disability
9) Criminology Music
10) Police Criminology
11) Criminology prevention
12) Criminology national security
13) Criminology emotions
14) Criminology of new technologies
15) Criminology of social protests
16) Criminology victims
17) Criminology human rights
18) Criminology social control
19) Ethnic criminology
20) Municipal criminology practice

\section{Publication of books and articles}

In chronological order, then the works have been published on the subject in Mexico and / or accessible procurement purposes of generating specialized knowledge are mentioned:

1. Hikal (2009), Introduction to the study of criminology and its methodology. The need to reorganize and systematize the criminological knowledge (where systematized for the first time specific criminologies), ISBN: 9786070901577

2 . (2009), Criminology Psychoanalytic, Behavioral and Development, ISBN: 9786077799078

3. (2010), Criminology, Human Rights and Individual Rights, ISBN: 9786070905131

4. (2011), Introduction to the study of criminology, ISBN: 9786070906626

5. (2011, 2015), Criminology etiological-multifactorial, ISBN: 9786077799658

$6 . \quad(2011,2013,2016)$, psychological criminology, ISBN: $\overline{9786070907876}$

7. Cunjama Ordaz Hernandez and Lopez (2011), Reflexive Criminology, ISBN: 9786078127085

8. Vozmediano Sanz and Guillen (2011), Environmental Criminology, ISBN: 9788497888745

9. Echeverria Solano (2012), Criminology Field, ISBN: 9786071710932

10. Hikal (2013), Criminology human rights, ISBN: 9786070914164

11. Ferro Veiga (2014), Criminology Chromatic, ISBN: 1230000276501

12. Lima Malvido (2014), Female Criminality, ISBN: 9789700713502
13. Rodríguez Manzanera (2014), Juvenile Delinquency, ISBN: 9789700712000

14. (2014), White Paper on teaching criminology in Mexico, ISBN: 97860778829404116

15. Hikal (2016), Guide for writing thesis and other research work for students of Criminology-Criminalistics, ISBN: 9786070923739

16. Ramos Pérez Tolentino and Erosa (2016), black book teaching criminology in MexicoISBN: 978607610421

17. Rodríguez Manzanera (2016), Classics of Criminology, ISBN: 9786070922619

18. Rodríguez Manzanera (2016), Clinical Criminology, ISBN: 9786070907975

19. Weor (2017), Fundamentals of Endocrinology and Criminology, ISBN: 9785892132961

20. Pámanes Palacios (2017), Contemporary Clinical Criminology, ISBN: 9786070926037

In Panama, between 2016 and 2017, Hikal published:

a. Sociological criminology, ISBN: 9789962710530

b. Developmental criminology, ISBN: 9789962710714

\section{Books coordinated}

a. Gomez Tagle (2014) (coordinator) Specialized criminologies, which brings together various professionals, lawyers and criminologists degree as authors in book chapters, ISBN: 9786077708070

b. Between 2016 and 2017, in Mexico, Hikal directs and coordinates with other professionals in your criminologists most bachelor, lawyer, sociologist, psychologist, Collection of Criminology, Criminology and Victimology Criminal, stressed that most coordinators they were criminologist and / or criminalists degree, since this professional has little presence as a leader in the authorship of books, articles and conferences.

With the titles:

a. Hikal (dir.) And Servera Rodríguez (coord.), Criminology Scientific, ISBN: 9786076103746

b. and Tieghi (coord.), Clinical Criminology and Penology multifactorial etiology, ISBN: 9786076103739

c. Behavioral Criminology, ISBN: 9786076104019

d. Biological Criminology, ISBN: 9786076104194

e. and Herrera Rodríguez (coord.), Experimental Criminology, ISBN: 9786076103975

f. Criminology Antisocial Personality, ISBN: 9786076103999

g. and Garcia Alvarez (coord.), Women Criminology, ISBN: 9786076103982

h. and market-Justinian (coord.), Children and Youth Criminology, ISBN: 9786076104002 
i. $\overline{9786076104026}$

j. $\quad$ and Romero Muñoz (coord.), Criminology Prison, ISBN: $\overline{9786076103913}$

k. _ Preventive Criminology, ISBN: 9786076103937

1. and Perez Vaquero (coord.), Selected Topics of contemporary crime, ISBN: 9786076103906

m. and Garcia Mercader (coord.), Victimology Criminal, ISBN: 9786076103852

n. Hernandez and Fernandez (coord.), Sociological Criminology, ISBN: 9786076104057

o. __ Criminology Security, ISBN: 9786076104064

p. and Perez Tolentino, Criminology violence, ISBN: $\overline{9786076104163}$

q. __ Criminal Law, ISBN: 9786076103784

r. and Romero Muñoz, criminologies Specialized, ISBN: 9786077708070

s. and Calixto Contreras (coord.), Educational Criminology, ISBN: 786076104033

\section{Articles}

Some contributions via article (limiting ourselves to the Mexican context) were carried out by few authors, namely the detected:

a. Fernandez Reyes, A.A. (2005). Film criminology. The causes of crime in Mexican cinema of the "golden age". Studies on Contemporary Cultures, 9 (21). Recovered from http://www. redalyc.org/articulo.oa?id=31602106

b. Hikal, W. (2009). Developmental criminology: the study of personality. Ciencia UANL, Universidad Autonoma de Nuevo Leon, 12 (2). Recovered from http://www.cienciauanl.uanl.mx/122/ciencia_sociedad.pdf

c. Hikal, W. (2010). sociological criminology. Law and Social Change, 28 (9). Recovered from http://www.derechoycambiosocial.com/ revista028/criminolog\%C3\%ADa_sociol\%C3\%B3gica.pdf

d. Gomez Tagle Lopez, E. and Juarez Rios, E. (2014). sexual criminology. Magazine IUS, 8 (34). Recovered from http://www.scielo.org.mx/scielo.php?script=sci arttext\&pid=S1870-2147201400020000

e. Hikal, W. (2011). Space criminology. Antisocial and criminal behavior beyond Earth. Criminology and justice. Recovered from http://cj-worldnews.com/spain/index.php/es/component/ $\mathrm{k} 2 /$ item/1766-criminolog\%C3\%ADa-espacial-las-conductasantisociales-y-delincuenciales-fuera-de- the earth

f. Hikal, W. (2014). Criminology Human Rights. The violation of human rights as criminogenic factor. Topic's. Digital Journal of Criminology and Security, 5 (36). Recovered from https://drive. google.com/file/d/0B5KnciAQemFKQnZFekQwTnF1M2M/ view?pref $=2 \&$ pli $=1$

g. Carrera Palao, RE (2017). biological criminology: A view from forensic genetics. Archives of Criminology, Private Security and
Forensics. 8. Recovered from https://drive.google.com/file/d/0B cni943DKuqQ2JiRUo3LWNITVk/view

h. Patio Rios, G. (2016). Criminology Human Rights. Desiderata for the prevention and control of crime. Archives of Criminology, Private Security and Forensics. 7. Recovered https://drive.google. com/file/d/0B cni943DKuqQjRQbkFMRmJZWjA/view

i. Van Oordt, LZ (2016). Labor criminology. inherent topics and vinculates of criminology in the workplace. Archives of Criminology, Private Security and Forensics. 7. Recovered https:// drive.google.com/file/d/0B_cni943DKuqZmNSb3cyRV12S2c/ view

It is clear that the last three articles were written by Peruvians, but published in Mexico. On the other hand, apparently writing articles with a specific title of criminology, it is of no interest or importance to writers.

In the digital journal Archives of Criminology, Private Security and Criminalistics, volume IX from August to December (2017) it has attempted to systematize a series of articles with approaches to specific criminologies Criminology Human Rights, Family, Information, Geographic, Criminal, Prison, Criminal Philosophy, Psychology, victimhood. Recovered from http://somecrimnl.es.t1/IXagosto_diciembre-2017.htm

various items were located in other Latin American countries such as Criminology Art, Women, Human Rights, Sexual, among others.

\section{Curriculum and courses}

In the curricula of undergraduate, master's and doctoral (Hikal, Perez Tolentino, Romero Muñoz, and Gutierrez Cruz, 2018), the only specific criminologies that are emerging are: Critical Criminology, Criminology Clinic, the curriculum of subjects include by specialized branches of other areas of knowledge, namely: Criminal Psychology, Criminal Sociology, Criminal Statistics, Human Rights Criminology and Criminal Anthropology, Criminal, Constitutional, among others, Criminal Policy, correctional treatment, Victimology, among others. In 2014, the criminologist's degree, Yadira Calixto Contreras, as then, the coordinator's degree in criminology at the University Institute Mexico, in the State of Mexico, took first curriculum with specialized subjects: Criminology Biological, of Human Rights, Psychological, Social, Children and Youth and Women, IT, Comparative, and a specialty area in Victimology: Victimology Criminal (Figure 1). Some other advances have been, in 2014, the Diploma in Criminology industrial applications in the current context where the first module, you start with the theme: The need to specialize to criminology: the specific criminologies. Aguascalientes organized by the Institute for Training Specialists and comprehensive investigation (Figure 2). In 2015, the Supreme Court of Justice of the Nation, through the House Legal Culture of Obregon, Sonora, Specific Days of criminologies were given (Figure 3). In 2018, among the Mexican Society of Criminology chapter Nuevo Leon and the Mexican Federation of Criminology and Criminalistics, launched the first International Diploma in criminologies Specific, divided into the following blocks: multifactorial etiological Criminology, Criminology of social phenomena, preventive Criminology, Criminology forensics, corporate Criminology, Criminology psychological, educational Criminology, Criminology human rights, Children and youth Criminology, Criminology Women, criminology terrorism, environmental criminology, among others (Figure 4). 

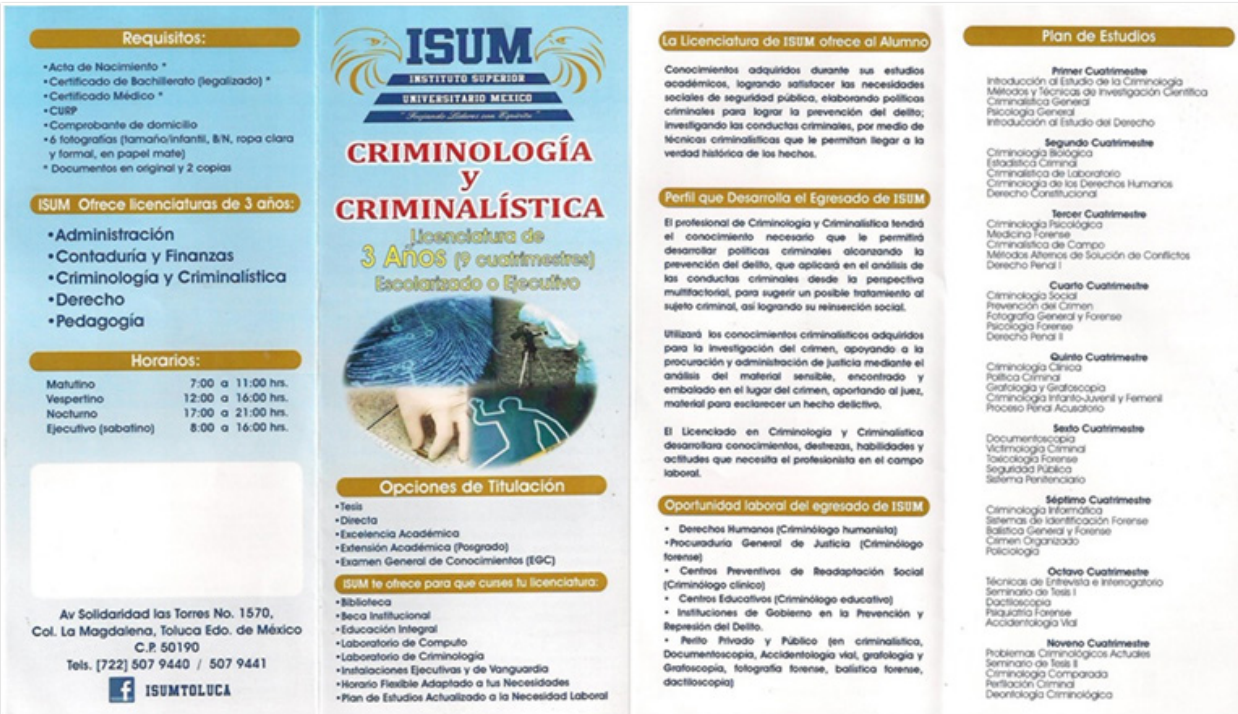

Figure I Degree in Criminology and Criminal. Instituto Superior Universitario Mexico.

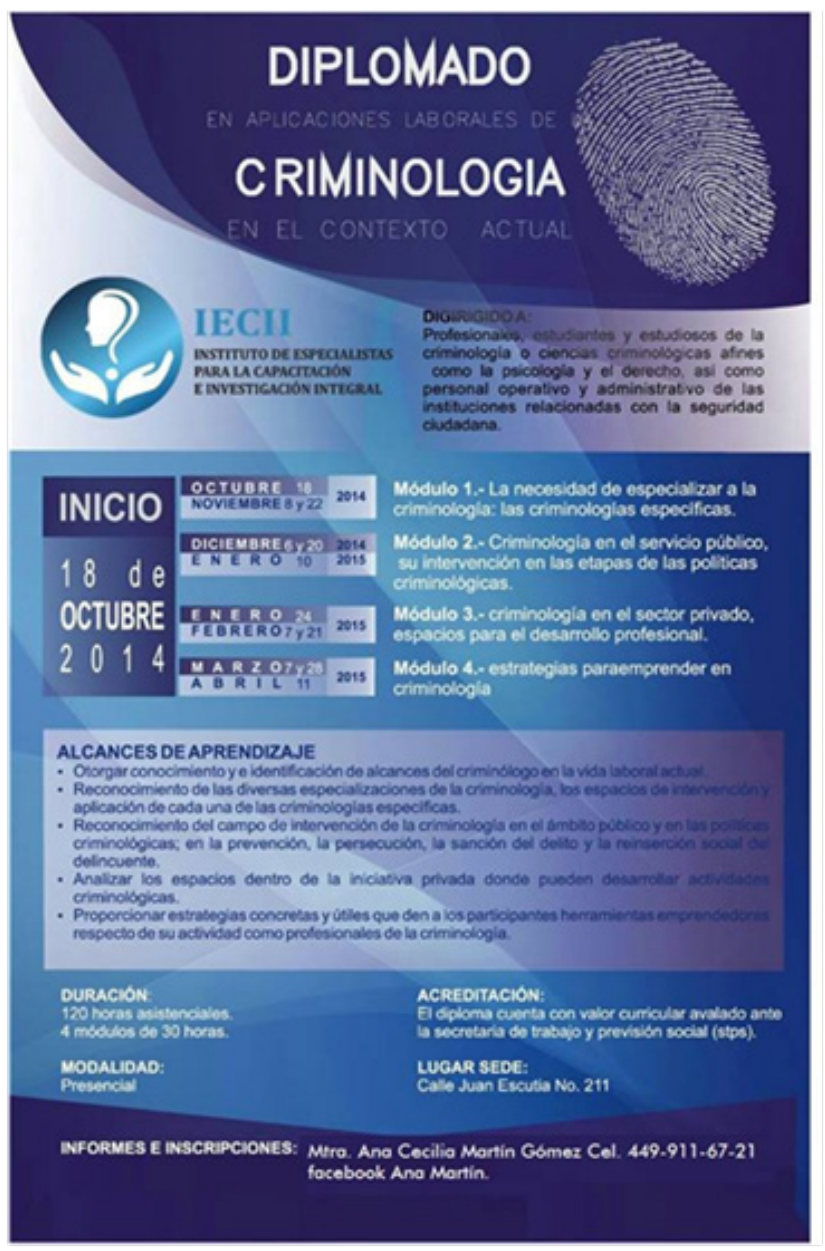

Figure 2 Diploma in Criminology. Specialist Institute for Training and Research Integral.

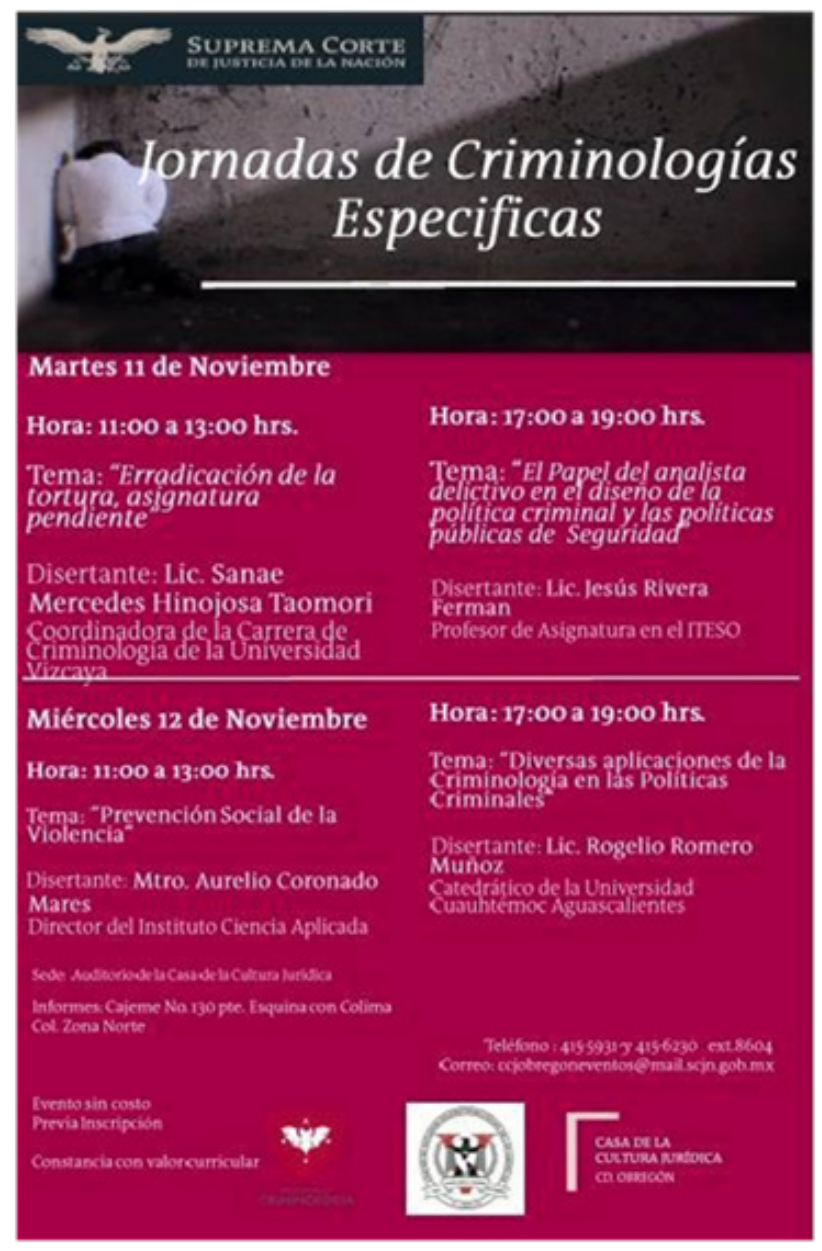

Figure 3 Specific Days criminologies. Supreme Court of Justice of the Nation. 

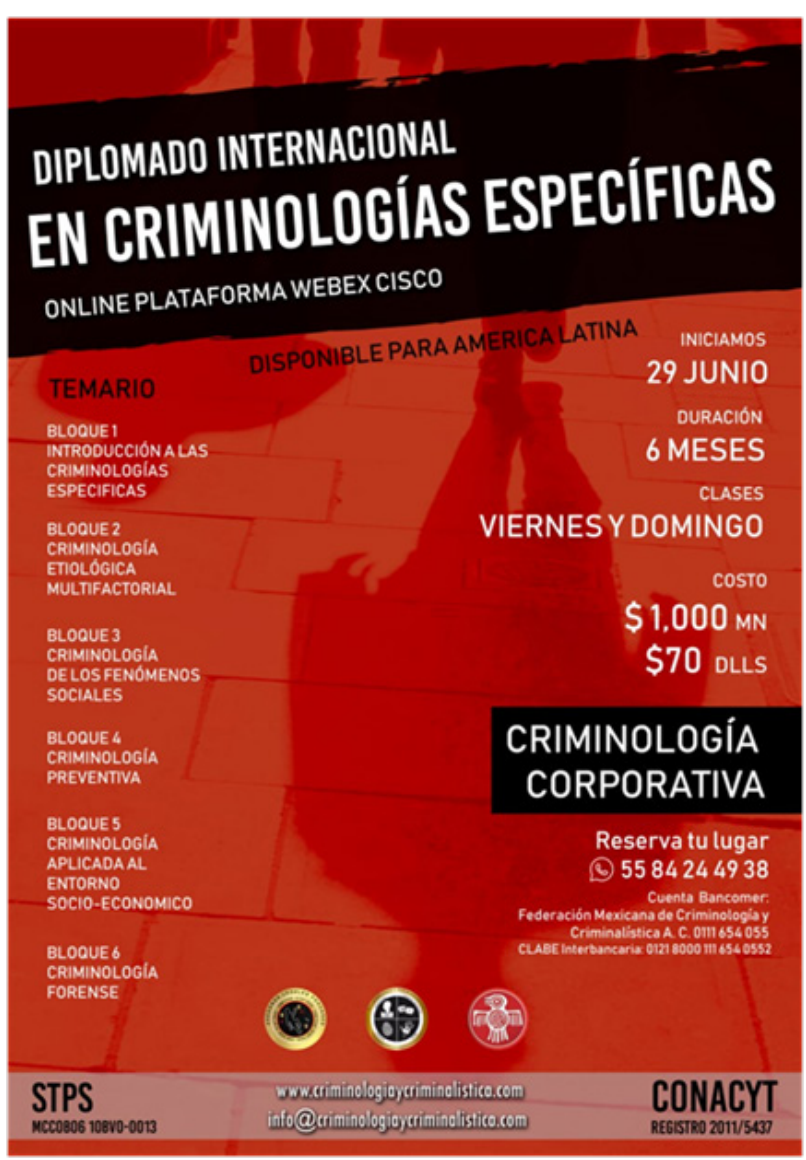

Figure 4 Specific International Diploma in criminologies. Mexican Society of Criminology Chapter Nuevo Leon and the Mexican Federation of Criminology and Criminalistics.

\section{Specialized magazines}

Another aspect are the magazines: How many magazines in Mexico there are about on Criminology, Criminology, Victimology and others? The most complex of the magazine itself-not the lack of magazines- is that criminologists-criminalists poorly publish in these, in the worst case (which is most common) not even known in undergraduate schools until later, teachers do not invite students to consult first-hand articles that are published in magazines therefore find current "cases" and so far, it is a bit complicated. It seems that criminologists-criminalists do not know-they do not want-not want to write, and expect a lawyer-criminologist, psychologist-criminologist or other writings make them. And what about the indexing of these ... It's a tricky issue.

Mexican magazines that are available in Mexico either digitally or in bookstores, specialty, not specific criminologies, but criminal, criminal, forensic and victimhood matter, the following are, limited only to those that are acquirable and Popular as well as ISSN, discarding those internal in schools or nongovernmental organizations that are limited to regional groups in a locality, have no or very hard, national impact. Nor magazines or Penal Law General, or others, psychology, sociology, etc., to address issues of violence-crime, which will be mentioned "in the same magazine can be found, sometimes in the same number as text below- of the most disparate tendencies " : 3
1. Archives of Criminology, Private Security and Forensics, ISSN 2007-2023

2. Criminalia, ISSN 1870-6509

3. Criminogenesis. specializing in Criminology and Criminal Law Journalof criminogenesis Group, ISSN 1870-9524

4. Iter criminis ISSN 1665-1464

5. Forensic science, ISSN 2007-2708

6. Penal system, ISSN 1870-9605

7. Vision Criminológica-Criminalistics, ISSN 2007-5804

In 2014 it was registered in the name of Wael Sarwat Hikal Carreon, the title of Revista Mexicana de criminologies Specific, subject to the exclusive use no. 04-2014-08410530800-203, but it was not able to consolidate, not existing any number posted yet.

\section{Zaffaroni says again:}

As for magazines, virtually no region in any magazine that does not include criminal law also subjects or criminological sections. As we have noted, many of our magazines are short-lived. ${ }^{3}$ (...) they are not exclusively devoted to criminological issues, but open their pages to the most diverse trends. ${ }^{3}$ In those magazines mentioned, no public entirely to the subject of specialized criminologies, but if there are any volumes where there is one other item to item, for example, introduction to specific criminologies, Environmental Criminology, Sexual, Sociological, IT, biological, psychological, among other. A comparison with the list of journals in criminology / criminal justice published by the American Society of Criminology (2006), which minimally include about 100 magazines, the situation in Mexico is limited only 7 known magazines. Of these, on the issue of index, some have about one to ten indices, only the first (Archives of Criminology), has about 60 indices, directors and databases, but not enough impact indicators appointment as Scopus, Psychoinfo, Thomson Reuters, Scielo, Index of Mexican Journals of science and technology, among others.

\section{Prizes awarded for scientific research}

In Mexico, have been given various awards, again, based only on the most public, they are concentrated in three organizations: American Society of Criminology, National Institute of Criminal Sciences and Mexican Society of Criminology Chapter Nuevo Leon.

\section{The first institution:}

(...) provides, once a year, the Medal of Merit Criminological named President founder, Dr. Alfonso Quiroz Cuarón. This award is the highest recognition in the art that is granted in our country, and is reserved to a (a) scientific Mexican national who has distinguished himself by his criminological work, in the chair, in the workplace and in his written (Mexican Society of Criminology, nd). From 1982 to 2015, it has been delivered to the classics today's criminal matter in Mexico, as well as disseminators of knowledge, on the other hand, note that only a criminologist's degree received in all those years, such medal. The second institution grants two awards: $\mathrm{PhD}$ because of honor, and honors academic merit, so far they have received various national and foreign, living and dead classics today, but there is no data of any criminologist's degree. For which candidates must have $e^{50}$ "sufficient professionals that have contributed systematic outstanding 
and continuously development, modernization, innovation and dissemination of Criminal Sciences academic merit or". And the last, in 2012, after consultation and approval of the authors who allowed his name to be reflected in medals and awards, medals to criminological merit were created: Osvaldo Tieghi Raul Zaffaroni, José Adolfo Reyes Calderon and Carlos Elbert, having been granted in 2012 and 2014, to merit investigations arising from the theoretical basis of previous authors. ${ }^{51-71}$

\section{Conclusion}

While criminology has grown unevenly; that is, there are more school degree (in Mexico), more graduate programs, more books (most of mere notions and reconstructions of the classics), magazines are scarce, as regards the production of knowledge has been lax, which from this view, reduces the labor insertacion, exercise and violence in Mexico and other countries.

\section{Acknowledgements}

None.

\section{Conflict of interest}

Author declares that there is no conflict of interest.

\section{References}

1. Peters T. The academic status of criminology. Notebook Basque Institute of Criminology: Eguzkilore; 2006.

2. Eskridge $\mathrm{C}$. The impact of education of criminal justice in the political and socio-economic climate of transition and developing nations. Archives of Criminology. 2013;1(2)

3. Zaffaroni. University teaching of criminology in Latin America.. Notebook Basque Institute of Criminology: Eguzkilore; 1990.

4. Flores publisher and distributor. Criminology. 2017.

5. Rodríguez Manzanera, L. Criminology. $18^{\text {th }}$ edn. Mexico: Porrúa; 2003.

6. Hikal, Ramos Erosa RA. black book teaching criminology in Mexico. $2^{\text {nd }}$ edn. Flores publisher and distributor: Mexico; 2016.

7. Hikal W. Guide for writing thesis and other research-student of Criminology Forensic science. $2^{\text {nd }}$ edn. Editorial Porrúa: Mexico; 2016.

8. Hikal. Etiological criminology-multifactorial. Security and Defense: Panama; 2016.

9. Hikal. Sociological Criminology. Security and Defense: Panama; 2016

10. Hikal, Tolentino Pérez, JA, et al. Census schools of Criminology, Criminology, Victimology and related criminal matters in Mexico. Mexican Society of Criminology: Leon; 2018.

11. National Council of Science and Technology. Brief History of CONACYT. 2012.

12. National Council of Science and Technology. Recognition of the National Institute of Penal Sciences and Public Research Center. 2012.

13. National Council of Science and Technology. National Research System 2014.

14. National Council of Science and Technology. Padrón National Quality Graduate Program. 2017.

15. National Council of Science and Technology. Padrón National Quality Graduate Program. 2017.
16. National Council of Science and Technology (2017). National Research System. 2017.

17. Hikal Glossary of Criminology, Criminology and Victimology Criminal. $2^{\text {nd }}$ edn. Flores publisher and distributor: Mexico; 2015.

18. Hikal. Criminology etiologic-multifactorial. $2^{\text {nd }}$ edn. Flores publisher and distributor: Mexico; 2015.

19. Reyes Calderon JA. Criminology. $3^{\text {rd }}$ edn. Cardenas Editor Distributor: Mexico; 2001

20. Tagle Gomez-Lopez. Specialized criminologies. Regulatory Advisory Designs: Mexico; 2014.

21. Zaffaroni. The criminal matter. Planet: Argentina; 2012.

22. Tieghi O. Criminal reflexology. Astrea: Argentina; 1974.

23. Drapkin I. Criminology of Violence. Ediciones DePalma: Argentina; 1984.

24. Tocaven García R. Children and Youth Criminology elements. Porrúa: Mexico; 1991.

25. Aniyar De Castro L. Criminology of social reaction. University of Zulia: Venezuela; 1977.

26. Hikal, Tieghi O, editors. Clinical criminology and criminologymultifactorial etiology. Flores publisher and distributor: Mexico; 2016.

27. Elbert C. Criminology. Science and social change. Editorial Universitaria de Buenos Aires: Argentina; 1996.

28. Palacios Pámanes GS. Contemporary criminology. Introduction to its theoretical foundations. National Institute of Penal Sciences: Mexico; 2012.

29. Hikal. Etiological criminology-multifactorial. Flores publisher and distributor: Mexico; 2011.

30. Hikal W. Specialization Criminology: Specific criminologies. Rebuttable. Universidad Anahuac Mexico: Mexico; 2017.

31. Cow-Cortes J. Is there something we might call "Criminology Ethnic"? While dialogue. 2105

32. Tagle Gomez-Lopez E. Criminology. Current challenges and prospects. Regulatory Advisory Designs: Mexico; 2011.

33. Arrue Hernandez MI. Let butting. Autodefensas Michoacan. Palibrio: USA; 2017.

34. Elbert. Epistemological nature of criminology. Criminology Latinoamericana (Part One). University: Argentina; 2012.

35. Bunge M. Political Philosophy. Solidarity, cooperation and Integral Democracy. Gedisa: Spain; 2009.

36. Birkbeck $\mathrm{CH}$, Martinez Corners JF. Criminology in Latin America: Balance and Perspectives. Council of Scientific, Humanistic and Technological Advice and Publications Board: Venezuela; 1992.

37. Torres M. Compulsive offender accused confesses and-- !: humanistic criminology. Third World Editors: Cuba; 1988.

38. Zambrano Pasquel A. Criminology issues: the reformist liberal criminology critical criminology. SESP. 1986.

39. Fontan Balestra C. Criminology and education. Hachette Bookstore: Argentina; 1943.

40. Teja Zambre A. Towards a Social Criminology. Notebooks Criminalia: Mexico; 1941

41. Encinoza Riera A, Olmo R. Towards a criminology of contradictions: the Latin American case. The Author: Venezuela; 1985. 
42. García Quimiz ET, Orlando Perdomo JW, Briones Fernández VH. Criminology: A dynamic science. Ecuador: Editorial Innovation and Development Area. 2017.

43. González Mongui PE. Criminal negative selection process. criminological research. Free University: Colombia; 2013.

44. Sued G. The criminal spectrum. The prohibitionist imaginary alternatives (dis) and penalizing human rights in the State of Puerto Rico Act. Crack: 2004.

45. Martinez E. Criminology and crime in the Dominican woman. Editora Universitaria: Dominican Republic; 1997.

46. Lopez Vergara J. Criminology: Introduction to the study of antisocial behavior. Western Institute of Technology and Higher Education: Mexico; 1991

47. Frame Pont L. Manual criminology: a modern approach. Porrúa: Mexico; 1986

48. Aparicio JE. Criminology - process and criminal enforcement, probation and Parole Board. Editorial Dimas: Argentina; 1985.

49. National Institute of Penal Sciences. Rules for granting recognition to the academic merit of INACIPE. 2010.

50. Mexican Society of Criminology Chapter Nuevo León. Criminological merit badges. 2012 .

51. Mexican Society of Criminology. Criminological Merit Medal.

52. Academia. edu. Curriculum vitae.

53. Bergalli R, Rivera Beiras I. To academic and legal education. Anthropos Spain; 2008.

54. Castillo Barrantes E. social life and law. University of Costa Rica and Legal Continental: Costa Rica; 2008.
55. Porrúa Editorial. Criminology. 2017.

56. Escobar Marulanda, G. Teaching in Criminology. Some considerations. Electronic Journal of Criminal Science and Criminology: 2008.

57. Free Law School Puebla. Our teachers.

58. Eumed. Dr. Julio César Kala.

59. Gallino L. Dictionary of Sociology. Siglo Veintiuno Editores: Mexico 1995

60. Iberian. Dr. Juan Federico Arriola Cantero.

61. INPOCIPE. Maria Teresa Ambrosio Morales.

62. Research tattoos. Interview with Victor Alejandro Payá Porres DR.

63. Márquez Algara MG. community mediation and crime prevention. Editorial Porrúa: Mexico; 2016.

64. Encinoza Riera A. Attempts to develop a Radical Criminology in Latin America: Crime of the bourgeoisie and constitutional crime. Universidad de los Andes. Venezuela; 1977.

65. Routledge Criminology. Criminology \& Criminal Justice. 2017.

66. American Society of Criminology. Partial list of criminology / criminal justice related journals. (2006).

67. Universidad Autonoma de Nuevo Leon. PhD in Criminology. 2014

68. Autonomous University of Baja California. Pablo Jesús González Reyes.

69. University of Colima. Catalogue.

70. Universidad Veracruzana. Lopez Contreras E. cardigan.

71. Zaffaroni. Criminology. Approach from a margin. Themis: Argentina; 2003. 